\title{
Enhanced Lignocellulolytic Enzyme Activities on Hardwood and Softwood during Interspecific Interactions of White- and Brown-Rot Fungi
}

\author{
Junko Sugano $^{1}$, Ndegwa Maina ${ }^{2}$, Janne Wallenius ${ }^{1}$ and Kristiina Hildén ${ }^{1, *}$ \\ 1 Department of Microbiology, Faculty of Agriculture and Forestry, University of Helsinki, \\ FI-00014 Helsinki, Finland; junko.sugano@helsinki.fi (J.S.); janne.wallenius@helsinki.fi (J.W.) \\ 2 Department of Food and Nutrition, Faculty of Agriculture and Forestry, University of Helsinki, \\ FI-00014 Helsinki, Finland; henry.maina@helsinki.fi \\ * Correspondence: kristiina.s.hilden@helsinki.fi
}

\section{check for} updates

Citation: Sugano, J.; Maina, N.; Wallenius, J.; Hildén, K. Enhanced Lignocellulolytic Enzyme Activities on Hardwood and Softwood during Interspecific Interactions of Whiteand Brown-Rot Fungi. J. Fungi 2021, 7, 265. https://doi.org/10.3390/ jof7040265

Academic Editors: Paul

Olusegun Bankole and

Dietmar Schlosser

Received: 15 March 2021

Accepted: 29 March 2021

Published: 31 March 2021

Publisher's Note: MDPI stays neutral with regard to jurisdictional claims in published maps and institutional affiliations.

Copyright: (c) 2021 by the authors. Licensee MDPI, Basel, Switzerland. This article is an open access article distributed under the terms and conditions of the Creative Commons Attribution (CC BY) license (https:// creativecommons.org/licenses/by/ $4.0 /)$.

\begin{abstract}
Wood decomposition is a sophisticated process where various biocatalysts act simultaneously and synergistically on biopolymers to efficiently break down plant cell walls. In nature, this process depends on the activities of the wood-inhabiting fungal communities that co-exist and interact during wood decay. Wood-decaying fungal species have traditionally been classified as white-rot and brown-rot fungi, which differ in their decay mechanism and enzyme repertoire. To mimic the species interaction during wood decomposition, we have cultivated the white-rot fungus, Bjerkandera adusta, and two brown-rot fungi, Gloeophyllum sepiarium and Antrodia sinuosa, in single and co-cultivations on softwood and hardwood. We compared their extracellular hydrolytic carbohydrate-active and oxidative lignin-degrading enzyme activities and production profiles. The interaction of white-rot and brown-rot species showed enhanced (hemi)cellulase activities on birch and spruce-supplemented cultivations. Based on the enzyme activity profiles, the combination of B. adusta and G. sepiarium facilitated birch wood degradation, whereas B. adusta and A. sinuosa is a promising combination for efficient degradation of spruce wood, showing synergy in $\beta$-glucosidase (BGL) and $\alpha$-galactosidase (AGL) activity. Synergistic BGL and AGL activity was also detected on birch during the interaction of brown-rot species. Our findings indicate that fungal interaction on different woody substrates have an impact on both simultaneous and sequential biocatalytic activities.
\end{abstract}

Keywords: wood decay; lignocellulose; carbohydrate active enzyme; laccase; white rot; brown rot; synergy

\section{Introduction}

Plant biomass degradation is a complex process where various enzymes act simultaneously and synergistically on diverse biopolymers in order to efficiently breakdown plant cell walls. In natural habitats, this process strongly depends on the activities of microbial communities. In boreal and temperate forests, white-rot and brown-rot basidiomycete species play an important role in carbon cycling due to their ability to efficiently degrade or modify main lignocellulosic polymers present in the wood cell walls [1,2]. White-rot fungi have a unique ability to degrade all wood cell wall polymers, whereas brown-rot fungi hydrolyze cellulose and hemicelluloses, leaving modified, mainly demethoxylated, lignin behind.

The different wood degradation approaches rely on a diverse repertoire of oxidative and hydrolytic extracellular enzymes secreted by wood-rotting fungal species [3]. Whiterot fungi are able to secrete a wide variety of carbohydrate active enzymes (CAZymes; www.cazy.org (accessed on 16 February 2021)) and lignin-modifying oxidoreductases (Table S1). White-rot fungi form the majority of wood-degrading basidiomycetes, and the most intensively studied species are commonly isolated from hardwoods [1], which have 
slightly higher cellulose and hemicellulose contents than softwoods [4]. White-rot species, Bjerkandera adusta, has the full repertoire of genes involved in cellulose and hemicellulose degradation. In addition, enzymes involved in lignin degradation, such as manganese peroxidase $(\mathrm{MnP})$ and laccase, have been detected (Table S2).

In contrast, brown-rot fungi produce only a limited set of lignocellulose depolymerizing enzymes [5]. Most brown rotters lack some cellulose-degrading enzymes, such as cellobiohydrolases (CBHs) [3,6], as well as lignin-modifying heme-peroxidases. Enzymatic hydrolysis of wood polysaccharides is enhanced by hydroxyl radicals via the non-enzymatic Fenton reaction $[7,8]$. Loss of wood strength is caused by the depolymerization of cellulose and hemicellulose, whereas lignin is only slightly modified [4]. Antrodia sinuosa and Gloeophyllum sepiarium are brown-rot species in the order Polyporales and Gloeophyllales, respectively. They are mainly found on decaying conifer trees, but they can also colonize hardwood [9-13]. In addition, they are both associated with degradation of wooden buildings [14]. A. sinuosa is an efficient cellulose degrader, and its genome includes gene models encoding cellulases and hemicellulases e.g., from glycoside hydrolase (GH) families 1, 2, 3, 5, 12 and 27, and auxiliary activities (AA) such as lytic polysaccharide monooxygenases and laccases (Table S2) [15]. G. sepiarium genome data is not available, but whole genome sequence and multi-omics data for a taxonomically related and well-studied model brown-rot species, Gloeophyllum trabeum, does exist [16-18]. G. trabeum has a typical repertoire of CAZyme-encoding genes detected in brown-rot species. On spruce wafers, G. trabeum has been reported to secrete endoglucanases, mannanases and xylanases. Both brown-rot species also have numerous gene models annotated to the CAZy family, AA3. The AA3 family includes enzymes from the glucose-methanol-choline oxidoreductase superfamily that catalyzes the formation of $\mathrm{H}_{2} \mathrm{O}_{2}$ for the Fenton reaction (Table S2).

Interaction between fungal species is fundamental in all stages of wood decay. Interspecific interactions have been studied in processes where the ecological roles of diverse species and their community dynamics have been in focus [19-22]. Although combative fungal interactions are common in nature, fungal co-occurrence and succession have also been observed on decaying wood [23,24]. The community structure, wood properties and different stages of wood decay have an impact on fungal enzyme activities, but only a few studies have targeted activity profiles of lignocellulosic substrates [25-31]. We have investigated the decay rate of wood species commonly found in Nordic boreal forests by cultivating white-rot and brown-rot fungi in different species combinations [32]. In this study, we investigated how the synergistically acting fungal species benefit from each other's enzymatic abilities when they were cultivated on these different wood species. In addition, enzyme synergy between different combinations of white-rot and brown-rot fungal species was examined.

\section{Materials and Methods}

\subsection{Fungal Cultures}

Two Basidiomycota brown-rot fungal species, Antrodia sinuosa (CBS 142277) and Gloeophyllum sepiarium (CBS 142272), and a white-rot species, Bjerkandera adusta (CBS 142279), were pre-cultured on $2 \%(w / v)$ malt extract agar plates at $28^{\circ} \mathrm{C}$ in the dark for 7 days. $100 \mathrm{~mL}$ of low-nitrogen asparagine-succinate medium (LN-AS, $\mathrm{pH}$ 4.5) [33] was supplemented with $1 \mathrm{~g}$ (dry weight) Pinus sylvestris (Scots pine), Picea abies (Norway spruce), Betula pendula (birch) sawdust or $0.1 \mathrm{~g}$ microcrystalline cellulose (Avicel ${ }^{\circledR} \mathrm{PH}-101$; Sigma-Aldrich, St. Louis, MO, USA) as sole carbon sources. LN-AS liquid cultures were inoculated with 64 small (ca. $3 \mathrm{~mm} \times 3 \mathrm{~mm}$ ) agar pieces cut from pre-cultivated agar plates $(2.5 \mathrm{~cm} \times 2.5 \mathrm{~cm}$ area). The fungal isolates were cultivated in single cultivations and in two species co-cultivations with agitation $(120 \mathrm{rpm})$ in the dark at $28^{\circ} \mathrm{C}$ for 35 days. All cultivations were performed with three biological replicates. 


\subsection{Enzyme Assays}

For enzyme activity measurements, $2 \mathrm{~mL}$ samples were taken twice a week from each cultivation flask. All the activities were calculated as $\mu \mathrm{kat} / \mathrm{L}$. Carbohydrate-active enzymes (CAZymes) and laccase (Lcc) activities were measured in 96-well microtiter plates using Tecan Spark version 1.2 (Tecan, Austria). $\beta$-1,4-Endoglucanase (EG), $\beta$-1,4-Endoxylanase $(\mathrm{XLN})$ and $\beta-1,4$-Endomannanase (MAN) activities were detected using a dinitrosalicylic acid assay [34] in $50 \mathrm{mM} \mathrm{Na-citrate} \mathrm{buffer,} \mathrm{pH}$ 4.8. For EG, XLN and MAN activity, $1 \%(w / v)$ carboxymethyl cellulose (CMC; Sigma-Aldrich, USA), 1\% ( $w / v)$ xylan from beechwood (Sigma, Neustadt, Germany) [35,36] and $0.5 \%(w / v)$ locust bean gum (Sigma-Aldrich, USA) [34] were used as substrates, respectively. The absorbance was measured at $540 \mathrm{~nm}$.

Exo-acting enzyme activities, $\beta-1,4$-Glucosidase (BGL), $\beta-1,4$-Xylosidase (BXL), $\beta$ 1,4-Mannosidase (MND) and $\alpha-1,4$-Galactosidase (AGL) were determined using the 4nitrophenyl (pNP) assay method at $405 \mathrm{~nm}$ with $0.1 \%$ of 4 -nitrophenyl $\beta$-D-glucopyranoside, 4-nitrophenyl $\beta$-D-xylopyranoside, 4-nitrophenyl $\beta$-D-mannopyranoside and 4-nitrophenyl $\alpha$-D-galactopyranoside, respectively, as substrates $[37,38]$. All pNP-linked substrates were purchased from Sigma-Aldrich (USA).

Cellobiohydrolase (CBHI) activity was measured using $2 \mathrm{mM}$ 4-methylumbelliferyl$\beta$-D-lactoside (MULac; Biokemis, Russia) in $50 \mathrm{mM}$ sodium citrate buffer (pH 5.0) as a substrate. The reaction was stopped with $1 \mathrm{M} \mathrm{Na}$-carbonate after incubation for $10 \mathrm{~min}$ at $45^{\circ} \mathrm{C}$, and the absorbance was measured at $370 \mathrm{~nm}$.

Lcc activity was determined at $476 \mathrm{~nm}$ by detecting the oxidation of 2,6-dimethoxyphenol (2,6-DMP; Aldrich, Darmstadt, Germany) in Mcllvain buffer, pH 3.0 and 5.0 [39]. The activity was calculated as nkat/mL. Manganese peroxidase $(\mathrm{MnP})$ activity was measured by following the formation of $\mathrm{Mn}^{3+}$-malonate complex at $270 \mathrm{~nm}$ in $0.05 \mathrm{M}$ Na-malonate buffer, pH 4.5, with Shimadzu UV-1700 PharmaSpec (Kyoto, Japan) [40].

\subsection{Statistical Analysis and Fungal Carbohydrate-Active Enzymes}

Enzyme activities of the co-cultivations were compared with both individual cultivations by one-way analysis of variance (ANOVA) or the Kruskal-Wallis test to determine significance at $5 \%$ level $(p<0.05)$. The Tukey HSD or Steel-Dwass test was used for multiple comparisons using statistical software R Version 3.6.1 and RStudio Version 1.2.5001 [41]. Homogeneity of variances $(p>0.05)$ was tested using the Levene or Fligner-Killeen test. A $t$-test was conducted to compare sugar compositions between untreated wood and fungal-treated wood.

\subsection{Substrate Composition Analysis}

Sugar compositions derived from hemicellulose of natural wood sawdust, fungal cultured wood sawdust and fungal mycelia were analyzed by acid methanolysis methods $[42,43]$. Ten milligrams $\pm 0.4 \mathrm{mg}$ of samples and sugar standards [arabinose (Ara), rhamnose (Rha), galactose (Gal), mannose (Man), galacturonic acid (GalA), glucuronic acid $(\mathrm{GlcA})$, glucose $(\mathrm{Glu})$ and xylose $(\mathrm{Xyl})]$ were weighed in pear-shaped flasks with three replications. The samples were dried in a vacuum oven at $30{ }^{\circ} \mathrm{C}$ for $30 \mathrm{~min}$. The samples were dissolved in $2 \mathrm{~mL}$ of an acid methanolysis reagent $(2 \mathrm{M} \mathrm{HCl}$ in anhydrous methanol) and incubated at $100^{\circ} \mathrm{C}$ for $5 \mathrm{~h}$. After cooling to room temperature, $100 \mu \mathrm{L}$ of pyridine was added to neutralize the samples. The solutions were filled up to $10 \mathrm{~mL}$ in the volumetric flasks. For the silylation, $100 \mu \mathrm{L}$ of internal standard ( $0.1 \%$ of sorbitol in methanol) was added to $2 \mathrm{~mL}$ of the methanolysis samples. After evaporating the solutions under nitrogen gas at $50{ }^{\circ} \mathrm{C}, 100 \mu \mathrm{L}$ of pyridine and $100 \mu \mathrm{L}$ of silylation reagent (1:99 of trimethylsilyi chloride (TMSCI) and N,O-Bis(Trimethylsilyl) trifluoroacetamide (BSTFA)) were added. The samples were incubated at $60^{\circ} \mathrm{C}$ for $30 \mathrm{~min}$, followed by addition of $1 \mathrm{~mL}$ of heptane.

Prior to gas chromatographic (GC) analysis, the samples were filtered $(0.45 \mu \mathrm{m}$, Acrodisc), and $1 \mu \mathrm{L}$ of each sample was injected into capillary column DB-1 (30 m/ $250 \mu \mathrm{m}$ Internal Diameter, $0.25 \mu \mathrm{m}$ filter thickness) in GC-MS 6890N (Agilent Technologies, California, USA) and measured at $250{ }^{\circ} \mathrm{C}$, split ratio 20:1. The temperature program was 
started with $150{ }^{\circ} \mathrm{C}(3 \mathrm{~min})$, a ramp of $2^{\circ} \mathrm{C} / \mathrm{min}$ to $186^{\circ} \mathrm{C}$ followed by a ramp of $1{ }^{\circ} \mathrm{C} / \mathrm{min}$ to $200{ }^{\circ} \mathrm{C}$ and $20{ }^{\circ} \mathrm{C} / \mathrm{min}$ to $300{ }^{\circ} \mathrm{C}(1 \mathrm{~min})$. The total run time was $40 \mathrm{~min}$. A frame ionization detector (FID) was used at $280{ }^{\circ} \mathrm{C}$. Helium was used as a carrier gas. All data were analyzed by a software, Agilent ChemStation (Agilent Technologies, Santa Clara, CA, USA). The dry weights of sugars were given as $\mathrm{g} / 100 \mathrm{~g}$ wood.

\section{Results}

\subsection{Hydrolytic Enzyme Activities}

\subsubsection{Cellulolytic Activities}

All fungal strains were cultivated in a minimal medium supplemented with either wood sawdust or Avicel. Selected enzyme activities targeting cellulose and hemicellulose were determined from liquid cultivations twice a week. In cultivations with birch and pine, EG and BGL activities were slightly higher compared to spruce (Figures 1, 2 and S1). EG activities stayed constant in all cultivation conditions. On day 24, co-cultivation of white-rot fungus, B. adusta, and brown-rot fungus, G. sepiarium, showed higher EG activity compared to single cultivations with birch $(2.6 \mu \mathrm{kat} / \mathrm{L})$ as carbon sources (Figure 1). On birch-supplemented conditions, towards the end of the cultivation period, EG activity was higher than with Avicel, which was prepared as a positive control. In the single cultivations, the highest activities (approx. $2.2 \mu \mathrm{kat} / \mathrm{L}$ ) were detected in brown-rot species, $A$. sinuosa and $G$. sepiarium, with pine as a sole carbon source.
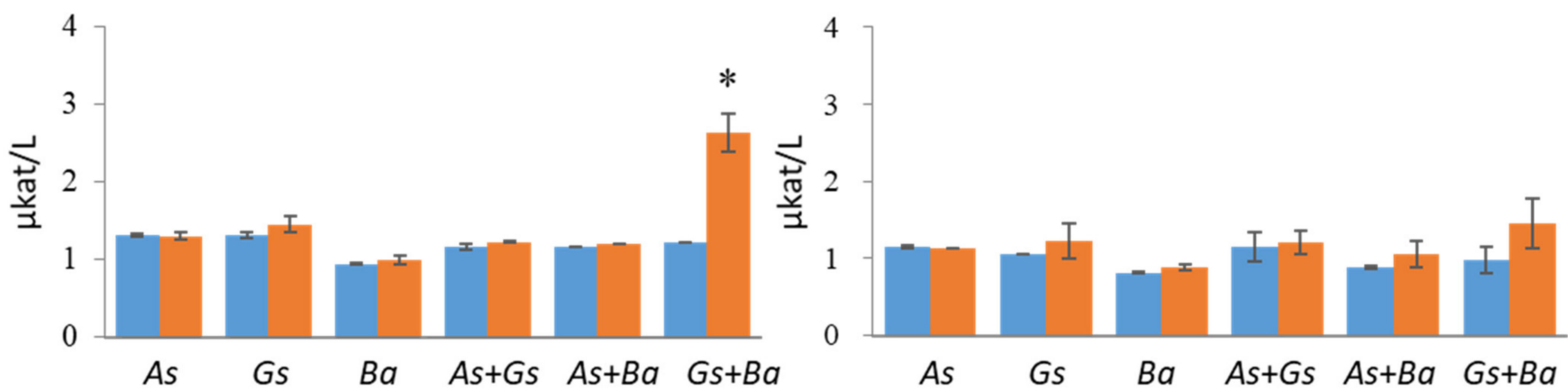



(c)

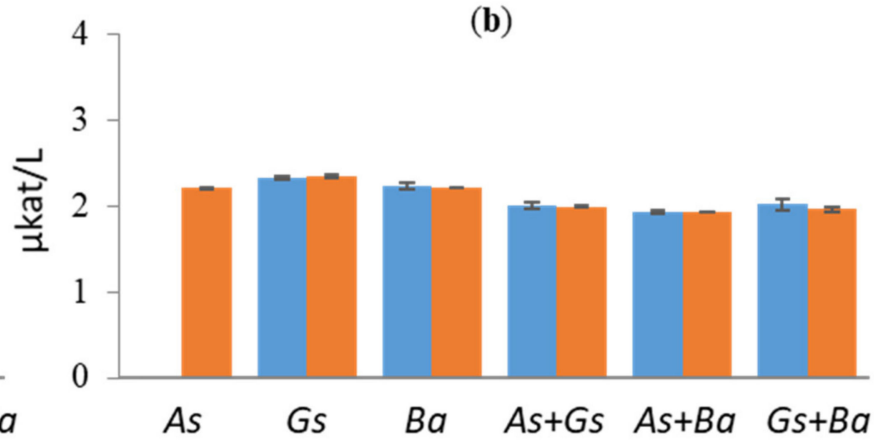

(d)

Figure 1. Endoglucanase (EG) activities at early (day 10, marked in blue) and late time points (day 24, marked in red) in single and co-cultivation on (a) birch, (b) spruce, (c) pine wood and (d) Avicel. As = A. sinuosa, Gs = G. sepiarium, Ba = B. $a d u s t a, A s+G s=A$. sinuosa and G. sepiarium, $A s+B a=A$. sinuosa and B. adusta, Gs+Ba=G. sepiarium and B. adusta. Error bars refer to standard deviation (SD) $(n=3)$. ${ }^{*}$ indicates statistical difference among single and co-cultivations $(p<0.05)$. 


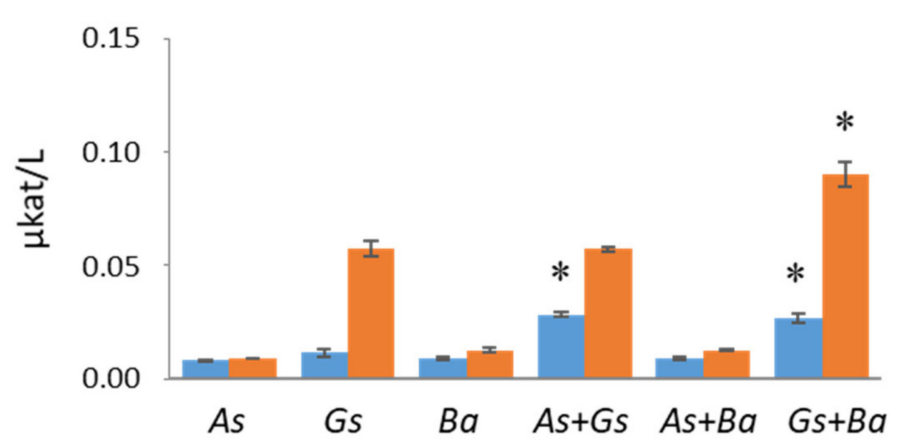

(a)

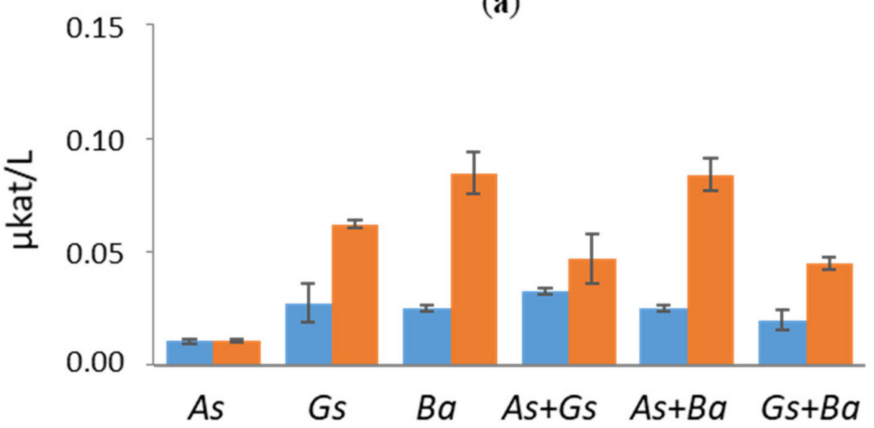

(c)

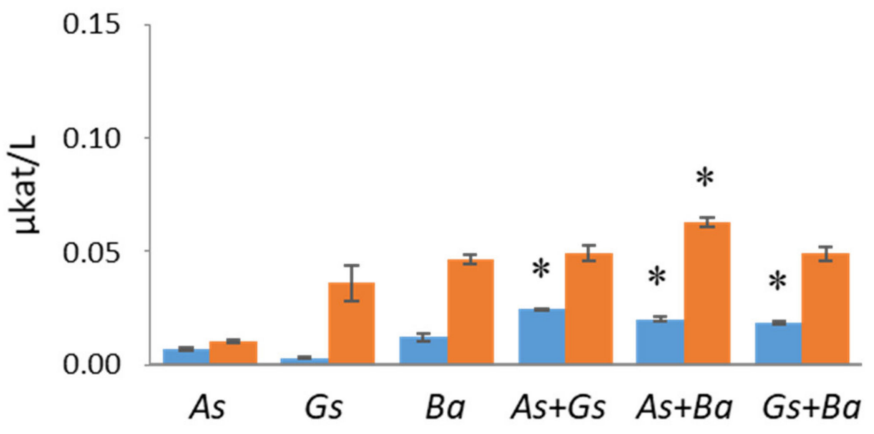

(b)

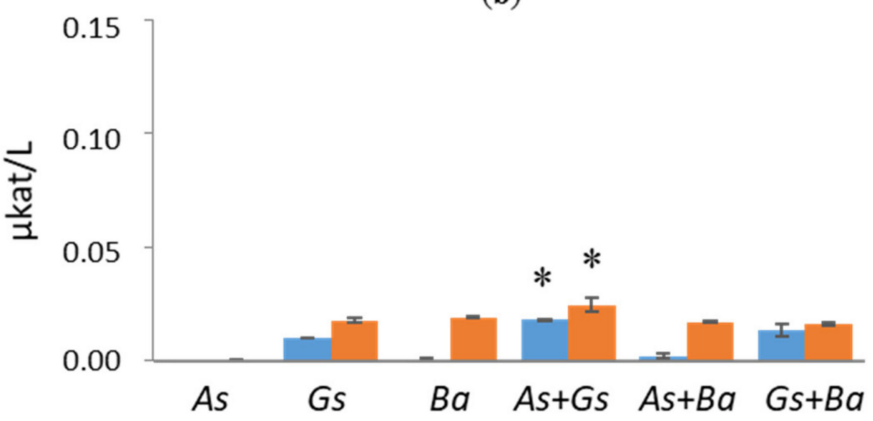

(d)

Figure 2. $\beta$-glucosidase (BGL) activities at early (day 10, marked in blue) and late time points (day 24 , marked in red) in single and co-cultivation on (a) birch, (b) spruce, (c) pine wood and (d) Avicel. As = A. sinuosa, Gs = G. sepiarium, Ba =B. $a d u s t a, A s+G s=A$. sinuosa and G. sepiarium, $A s+B a=A$. sinuosa and B. adusta, $G s+B a=G$. sepiarium and B. adusta. Error bars refer to standard deviation $(\mathrm{SD})(n=3) .{ }^{*}$ indicates statistical difference among single and co-cultivations $(p<0.05)$.

Co-cultivated B. adusta and G. sepiarium indicated synergistic BGL activity both at early $(0.03 \mu \mathrm{kat} / \mathrm{L})$ and late time points $(0.09 \mu \mathrm{kat} / \mathrm{L})$ of cultivation on birch (Figure 2$)$. Synergistic effects on BGL activity were also detected in G. sepiarium co-cultivations with A. sinuosa at day 10 on birch $(0.03 \mu \mathrm{kat} / \mathrm{L})$, which turned into additive effects towards the end of the cultivation (Figure S2). In B. adusta, BGL activity was the highest in softwoodcontaining cultivations, reaching $0.08 \mu \mathrm{kat} / \mathrm{L}$ on pine and $0.05 \mu \mathrm{kat} / \mathrm{L}$ on spruce (Figure 2). BGL activities were low in Avicel-containing cultivations throughout the cultivation period.

CBHI activity was detected only in white-rot species, B. adusta, cultivations supplemented with softwood (Figures 3 and S3). Surprisingly, co-cultivation of B. adusta together with brown-rot species, $A$. sinuosa or G. sepiarium, showed enhanced CBHI activity in the presence of birch $(0.21 \mu \mathrm{kat} / \mathrm{L})$ and spruce $(0.13 \mu \mathrm{kat} / \mathrm{L})$, respectively, at day 24 of the cultivation. However, in pine-containing growth conditions, co-cultivations reduced CBHI activity of B. adusta. CBHI activities were negligible in Avicel cultivation.

\subsubsection{Hemicellulolytic Activities}

Co-cultivation of B. adusta with G. sepiarium showed the highest XLN and BXL activities on birch (Figures 4 and 5). XLN activity of the co-cultivation started to increase after three weeks, reaching $3.8 \mu \mathrm{kat} / \mathrm{L}$ on day 35 (Figure S4), and BXL activity showed a constant rise from day three $(0.012 \mu \mathrm{kat} / \mathrm{L})$ to the end of the cultivation $(0.025 \mu \mathrm{kat} / \mathrm{L})$ (Figure S5). The highest XLN activities in co-cultivations were detected in pine during the interaction of brown rotters, G. sepiarium and $A$. sinuosa, where activity started to increase after one week, reaching $4.5 \mu \mathrm{kat} / \mathrm{L}$ on day 28 (Figure S4). However, even higher XLN activities (6.2 $\mu \mathrm{kat} / \mathrm{L})$ were detected in a single cultivation of G. sepiarium (Figure 4). On birch-supplemented cultivations, XLN and BXL activities stayed constant throughout the cultivation period, whereas XLN activities in pine- and spruce-supplemented cultivations fluctuated. In Avicel, activities towards xylan were low in all cultivation conditions and species. 


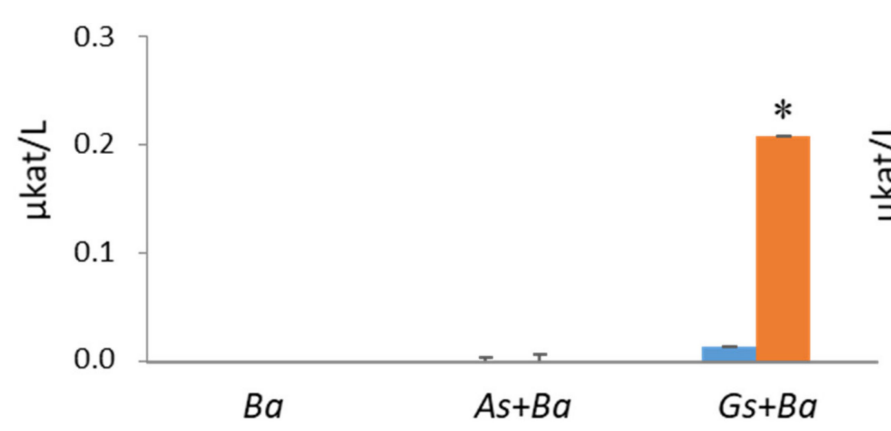

(a)

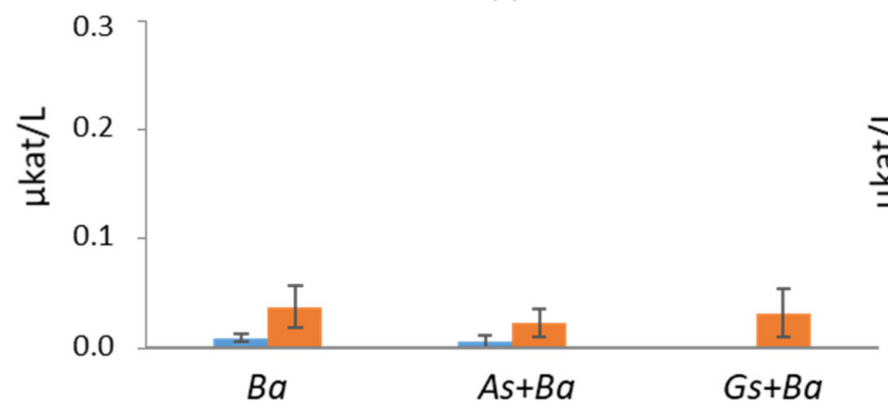

(c)

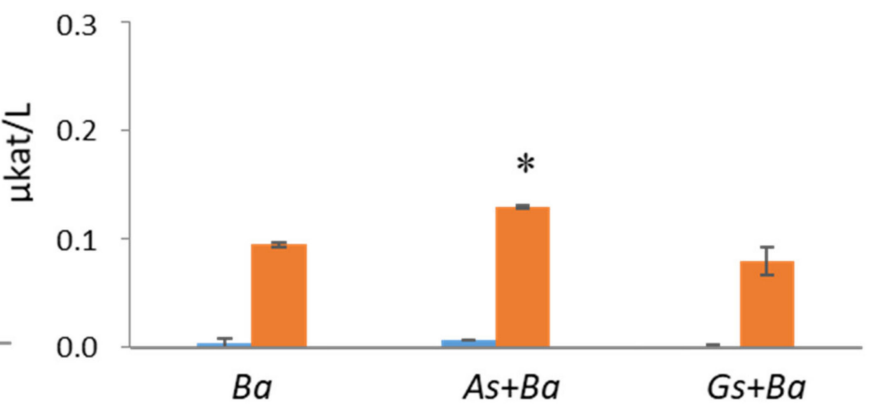

(b)

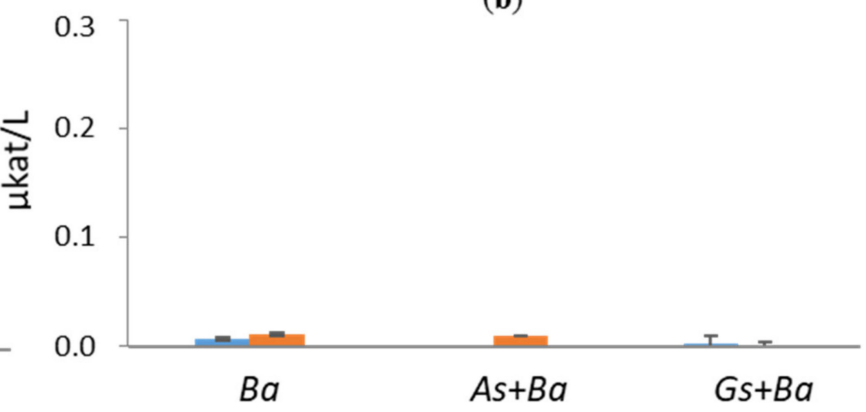

(d)

Figure 3. Cellobiohydrolase I (CBHI) activities at early (day 10, marked in blue) and late time points (day 24, marked in red) in single and co-cultivation on (a) birch, (b) spruce, (c) pine wood and (d) Avicel. $B a=B$. adusta, As+Ba=A. sinuosa and $B$. $a d u s t a, G s+B a=G$. sepiarium and B. adusta. Error bars refer to standard deviation (SD) $(n=3)$. * indicates statistical difference between B. adusta and co-cultivation with brown-rot species $(p<0.05)$.
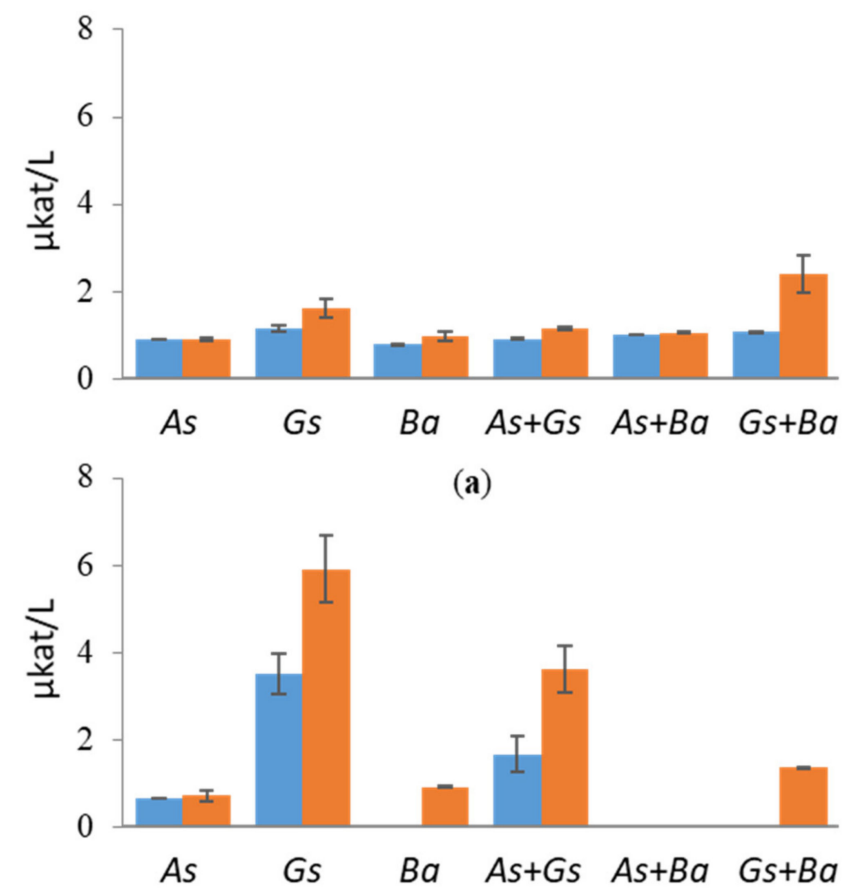

(c)

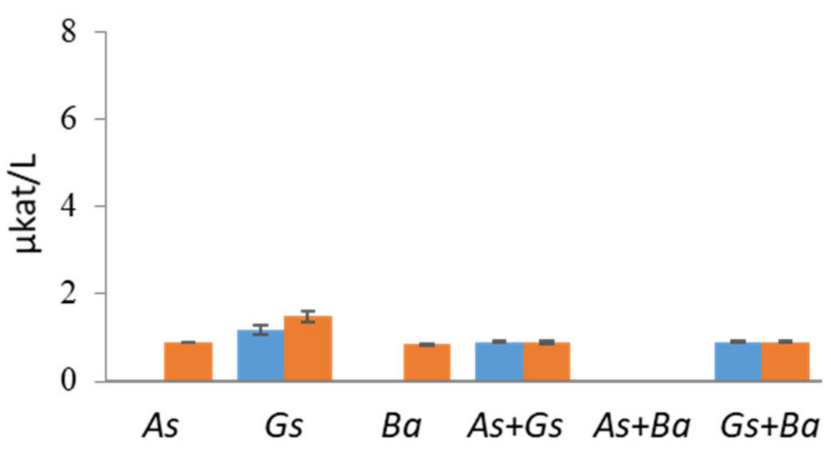

(b)

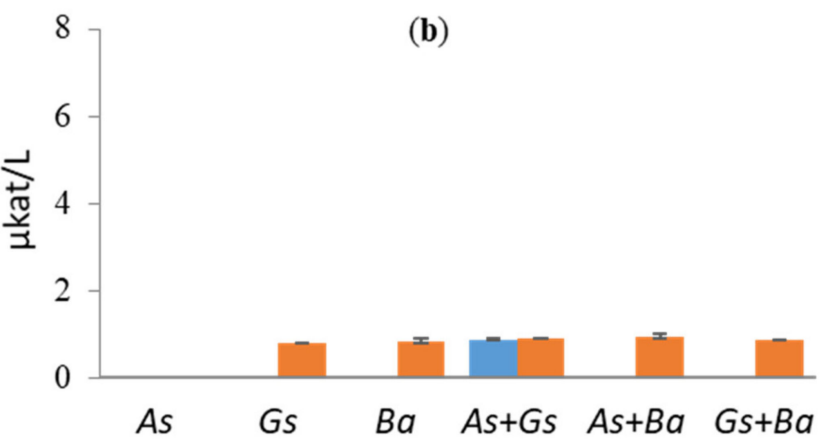

(d)

Figure 4. Endoxylanase (XLN) activities at early (day 10, marked in blue) and late time points (day 24, marked in red) in single and co-cultivation on (a) birch, (b) spruce, (c) pine wood and (d) Avicel. As = A. sinuosa, Gs = G. sepiarium, Ba=B. $a d u s t a, A s+G s=A$. sinuosa and G. sepiarium, $A s+B a=A$. sinuosa and B. adusta, $G s+B a=G$. sepiarium and B. adusta. Error bars refer to standard deviation $(\mathrm{SD})(n=3) .{ }^{*}$ indicates statistical difference among single and co-cultivations $(p<0.05)$. 


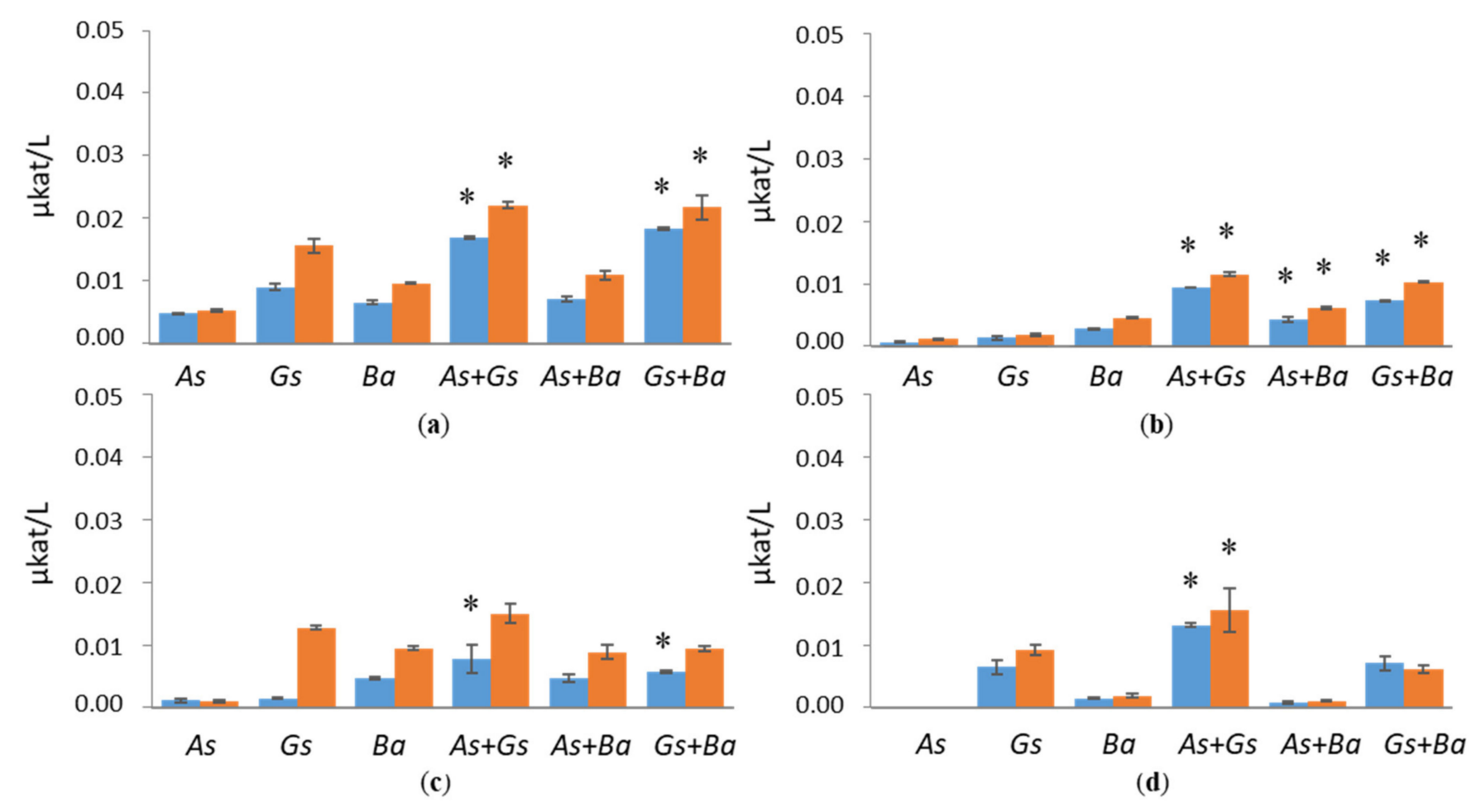

Figure 5. $\beta$-xylosidase (BXL) activities at early (day 10, marked in blue) and late time points (day 24, marked in red) in single and co-cultivation on (a) birch, (b) spruce, (c) pine wood and (d) Avicel. As = A. sinuosa, Gs = G. sepiarium, Ba=B. $a d u s t a, A s+G s=A$. sinuosa and G. sepiarium, $A s+B a=A$. sinuosa and B. adusta, Gs+Ba=G. sepiarium and B. adusta. Error bars refer to standard deviation $(\mathrm{SD})(n=3) .{ }^{*}$ indicates statistical difference among single and co-cultivations $(p<0.05)$.

MAN and MND exhibited almost flat activities in all cultivation conditions (Figures 6 and 7). MAN activities in pine-containing conditions showed fluctuation in all single and co-cultivations except in the $A$. sinuosa single cultivation, where MAN activity stayed approximately $3.8 \mu \mathrm{kat} / \mathrm{L}$ throughout the cultivation period (Figure S6). Cocultivated A. sinuosa and G. sepiarium showed higher MAN and MND activities on most of the wood-supplemented cultivations compared to the single cultivations (Figures 6 and S7). Surprisingly, for both brown-rot species, the highest MAN activities were detected on Avicel, whereas B. adusta showed no activity.

The highest AGL activity was detected in the G. sepiarium single cultivation on spruce -containing medium, where the activity was constantly growing during the cultivation period, being $0.18 \mu \mathrm{kat} / \mathrm{L}$ on day 35 (Figure S8). On birch- and pine-supplemented cultivations, the activity peaked in the second week of cultivation, reaching $0.09 \mu \mathrm{kat} / \mathrm{L}$. G. sepiarium co-cultivated either with $A$. sinuosa or B. adusta showed the highest activity on birch-containing medium (Figure 8). Both combinations showed synergistic activity at the end of the cultivation period (0.10 and $0.15 \mu \mathrm{kat} / \mathrm{L} ;$ Figure S8). Synergy was also detected in co-cultivated A. sinuosa and B. adusta on spruce $(0.05 \mu \mathrm{kat} / \mathrm{L})$, whereas the corresponding single cultivations showed activities below 0.008 and $0.03 \mu \mathrm{kat} / \mathrm{L}$, respectively. Both MND and AGL activities were low on Avicel (Figures 7 and 8). G. sepiarium showed low AGL activity in a single cultivation and together with $A$. sinuosa. 


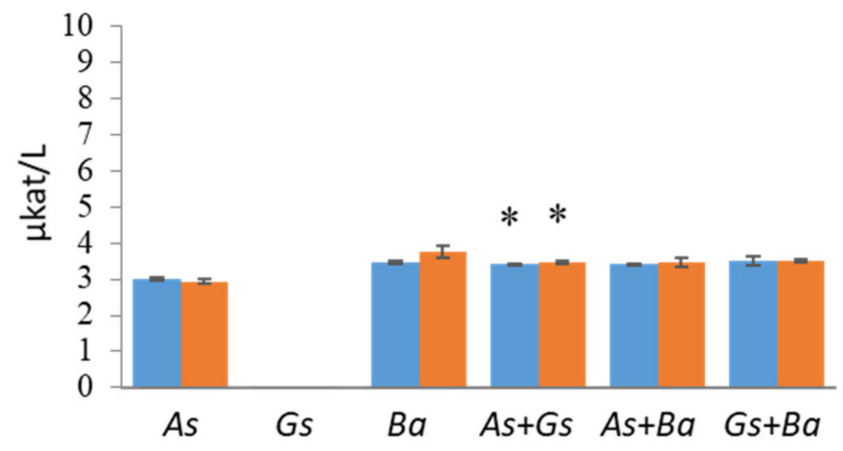

(a)

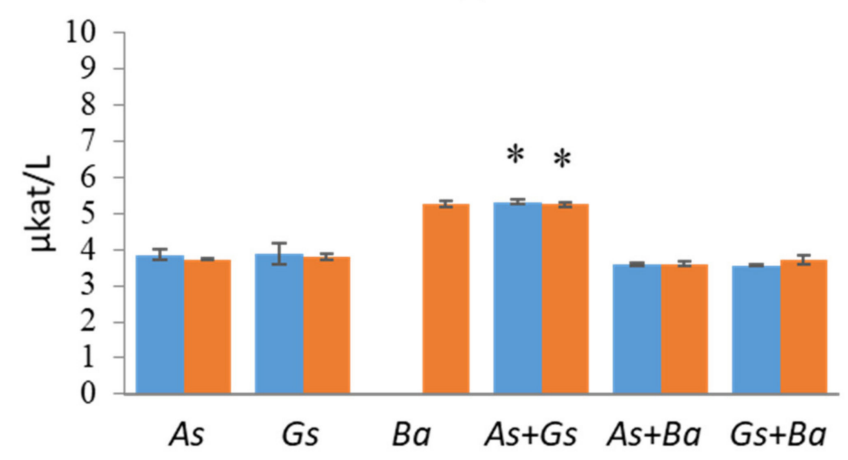

(c)

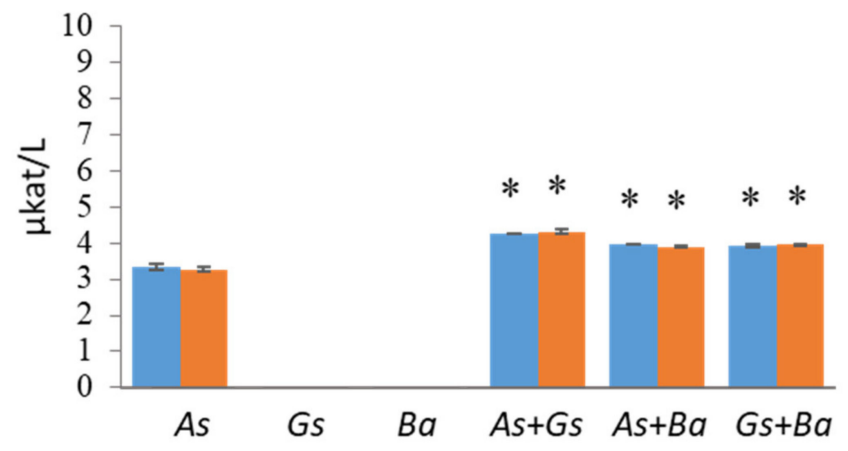

(b)

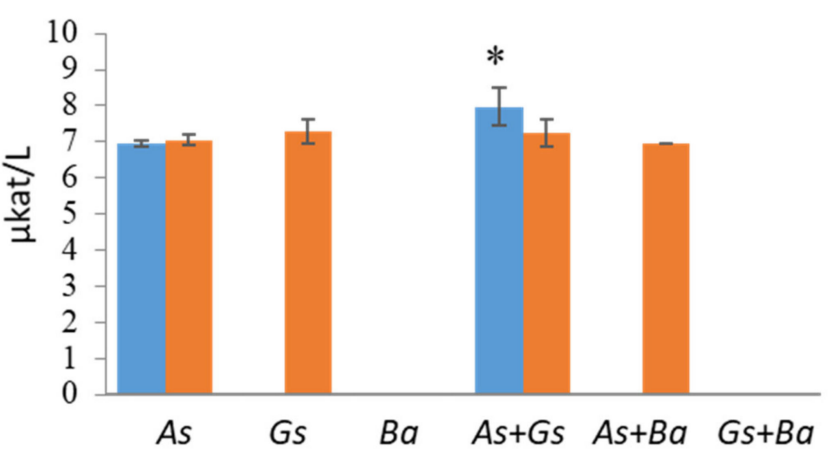

(d)

Figure 6. Endomannanase (MAN) activities at early (day 10, marked in blue) and late time points (day 24, marked in red) in single and co-cultivation on (a) birch, (b) spruce, (c) pine wood and (d) Avicel. $A s=A$. sinuosa, Gs = G. sepiarium, Ba=B. $a d u s t a, A s+G s=A$. sinuosa and G. sepiarium, $A s+B a=A$. sinuosa and B. adusta, Gs+Ba=G. sepiarium and B. adusta. Error bars refer to standard deviation (SD) $(n=3)$. ${ }^{*}$ indicates statistical difference among single and co-cultivations $(p<0.05)$.
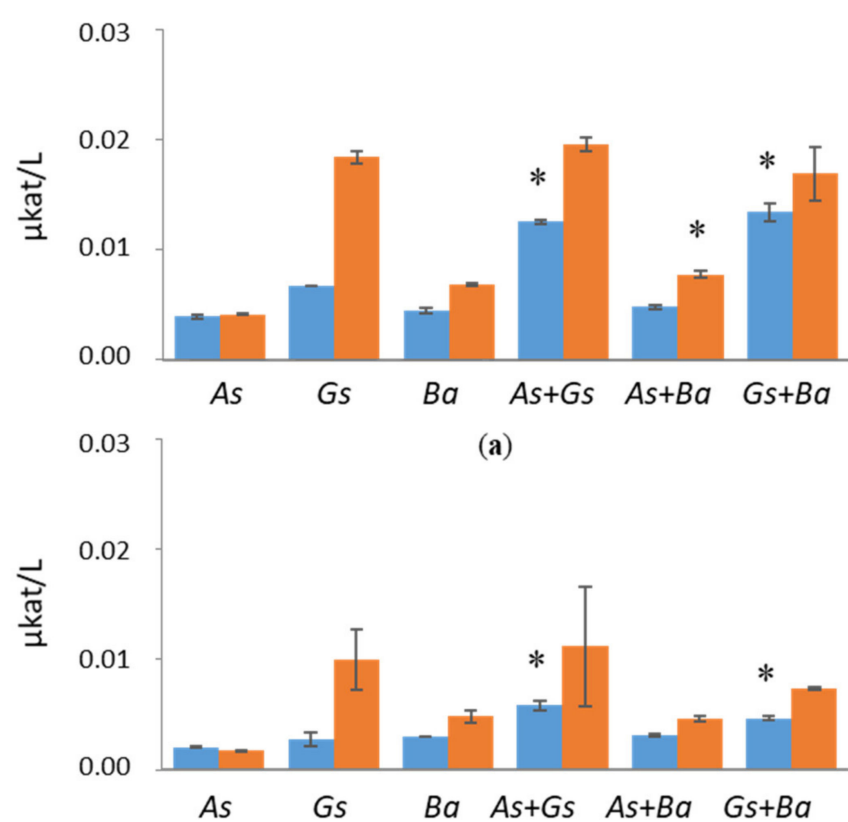

(c)

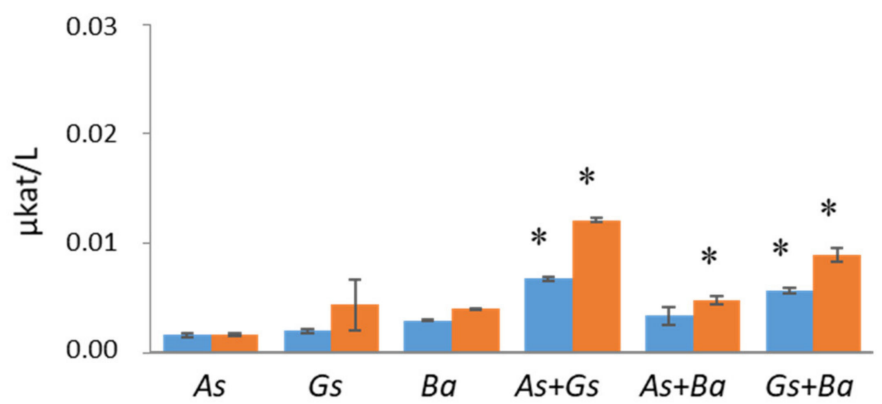

(b)

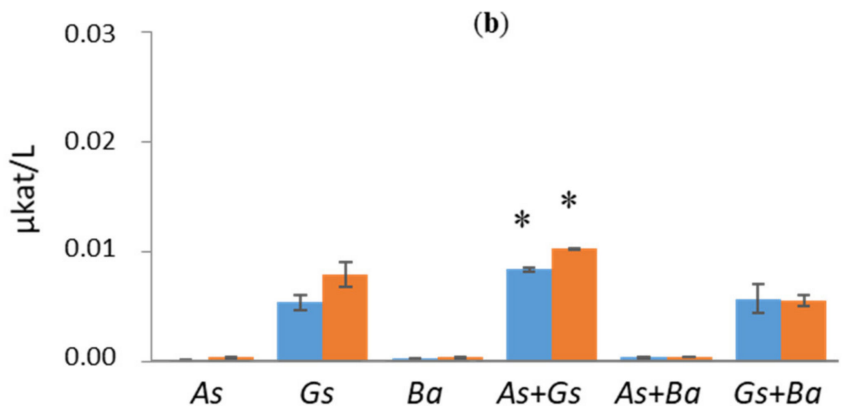

(d)

Figure 7. $\beta$-mannosidase (MND) activities at early (day 10, marked in blue) and late time points (day 24, marked in red) in single and co-cultivation on (a) birch, (b) spruce, (c) pine wood and (d) Avicel. $A s=A$. sinuosa, Gs = G. sepiarium, Ba=B. $a d u s t a, A s+G s=A$. sinuosa and G. sepiarium, $A s+B a=A$. sinuosa and B. adusta, Gs+Ba=G. sepiarium and B. adusta. Error bars refer to standard deviation (SD) $(n=3)$. * indicates statistical difference among single and co-cultivations $(p<0.05)$. 

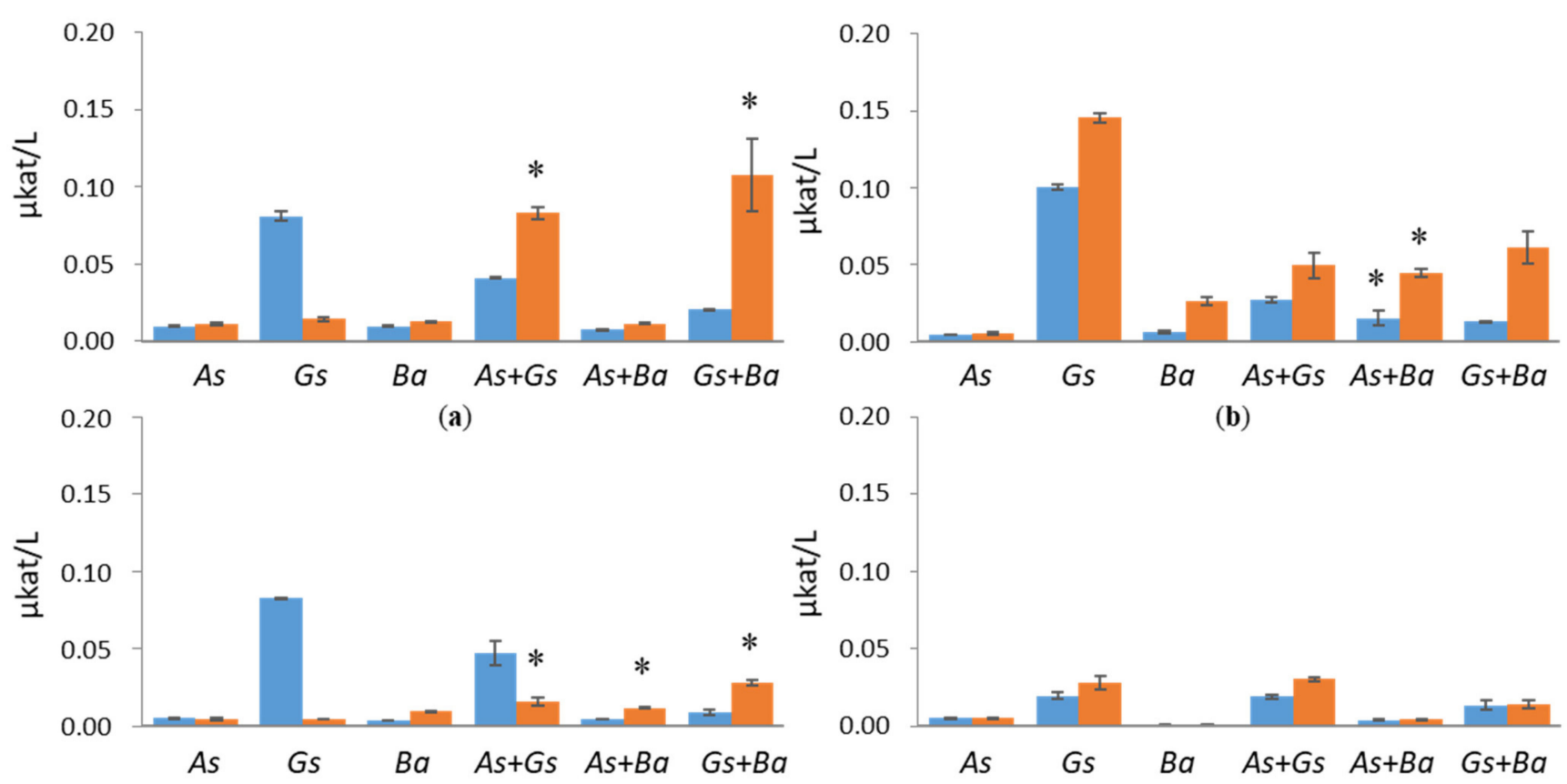

(c)

(d)

Figure 8. $\alpha$-galactosidase (AGL) activities at early (day 10, marked in blue) and late time points (day 24, marked in red) in single and co-cultivation on (a) birch, (b) spruce, (c) pine wood and (d) Avicel. $A s=A$. sinuosa, Gs = G. sepiarium, Ba=B. $a d u s t a, A s+G s=A$. sinuosa and G. sepiarium, $A s+B a=A$. sinuosa and B. adusta, Gs+Ba=G. sepiarium and B. adusta. Error bars refer to standard deviation $(\mathrm{SD})(n=3) .{ }^{*}$ indicates statistical difference among single and co-cultivations $(p<0.05)$.

\subsection{Activities of Lignin-Degrading Enzymes}

In general, activities related to lignin degradation (MnP and Lcc) were low (Figures 9 and 10). In B. adusta, the highest MnP activity was detected on the sprucecontaining cultivation at day $7(1.2 \mu \mathrm{kat} / \mathrm{L}$; Figure S9). However, when B. adusta was cocultivated with G. sepiarium, MnP activity on pine showed $2.3 \mu \mathrm{kat} / \mathrm{L}$ on day 10 (Figure 9). Lcc activities in all single cultivations were negligible. Only co-cultivated B. adusta and $A$. sinuosa showed low but clear activity on spruce with a synergistic potential $(0.4 \mu \mathrm{kat} / \mathrm{L}$; Figure 10).

\subsection{Wood Composition after Fungal Treatment}

The chemical composition of birch, spruce and pine was analyzed before and after fungal treatment (Table 1). In untreated softwoods, the most abundant hemicellulosederived monosaccharide was mannose (10.8\% in pine and $10.3 \%$ in spruce), whereas xylose dominated in birch $(21.4 \%)$. The amount of glucomannan-derived monosaccharides i.e., mannose (Man) and glucose (Glu), in pine were significantly reduced after fungal treatment, as well as pectin-derived GalA. Only on the A. sinuosa single cultivation, the reduction was not statistically significant. In contrast, in spruce-containing cultivations, the amount of mannan-derived monosaccharides were not affected by fungal treatment. On birch, the xylan-derived monosaccharide, xylose (Xyl), was significantly decreased in co-cultivated A. sinuosa and B adusta, as well as in the single cultivation of B. adusta. Both brown-rot species in single and co-cultivations showed significant losses of Glu derived from hemicelluloses in birch. 


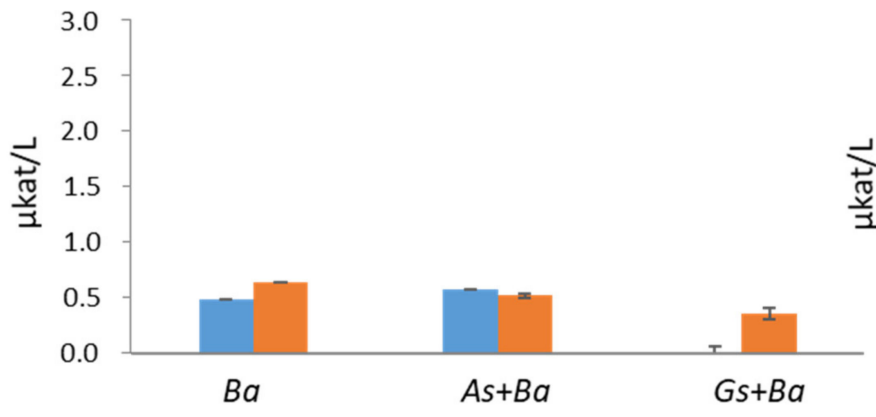

(a)

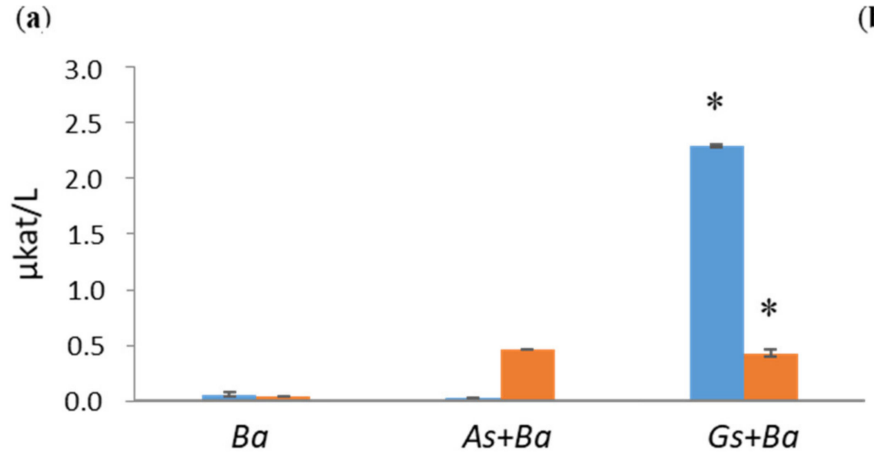

(c)

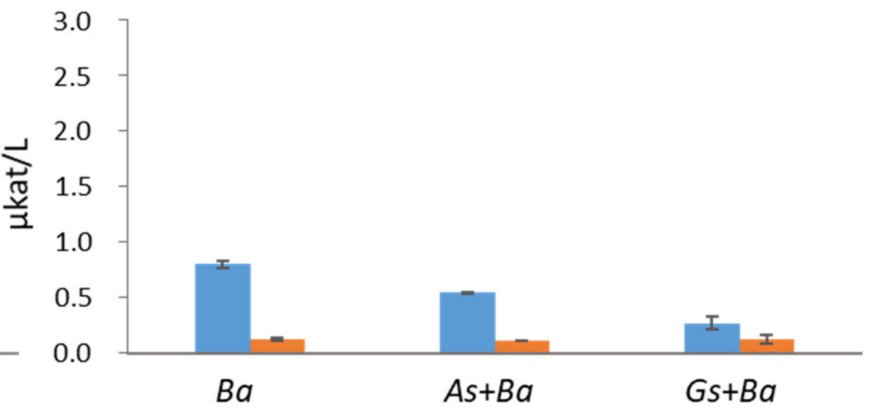

(b)

Figure 9. Manganese peroxidase ( $\mathrm{MnP}$ ) activities at early (day 10, marked in blue) and late time points (day 24, marked in red) in single and co-cultivation on (a) birch, (b) spruce and (c) pine wood. Ba = B. adusta, $A s+B a=A$. sinuosa and B. adusta, $G s+B a=G$. sepiarium and B. adusta. Error bars refer to standard deviation (SD) $(n=3) .{ }^{*}$ indicates statistical difference among single and co-cultivations $(p<0.05)$.

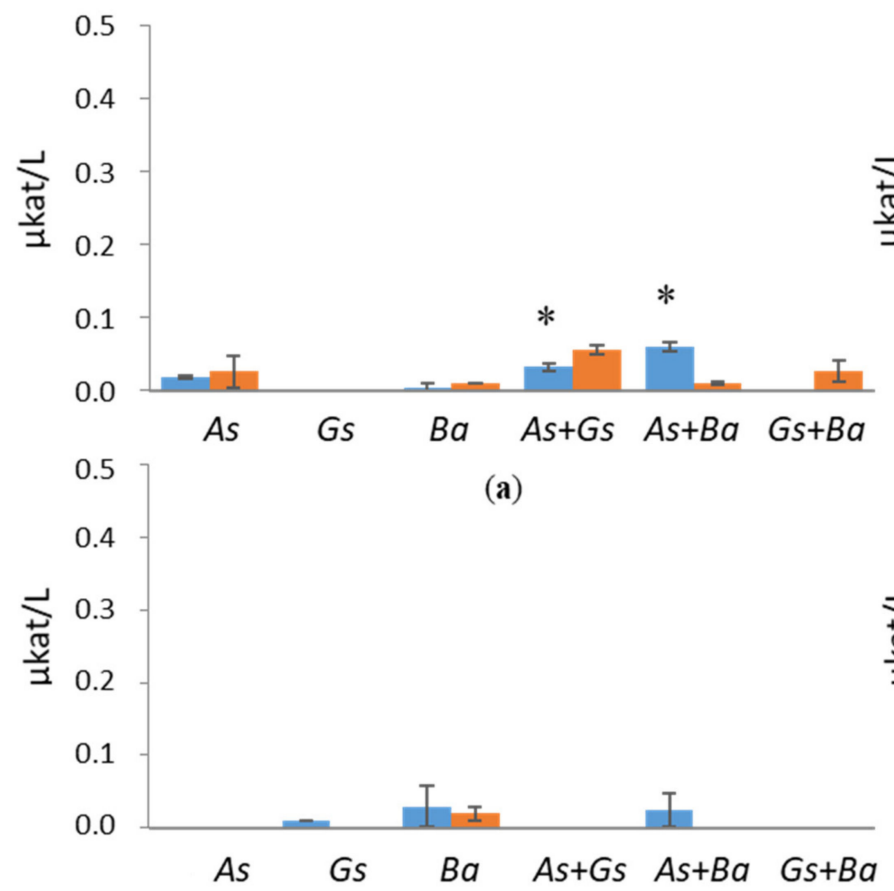

(c)

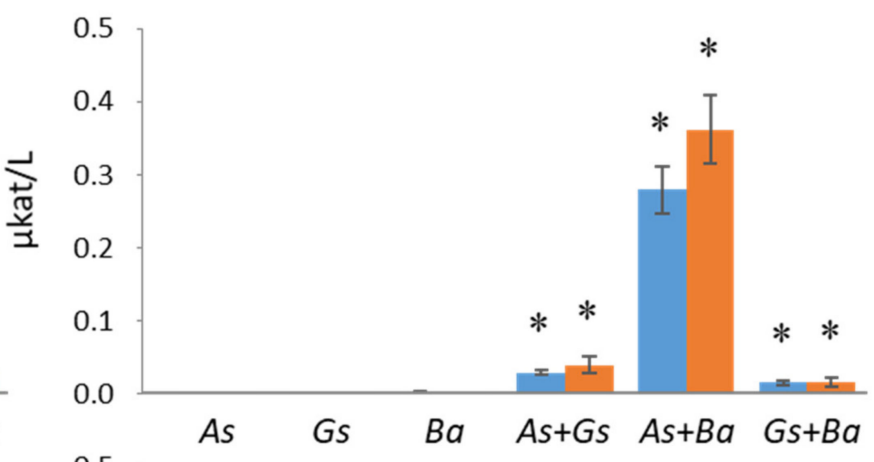

(b)

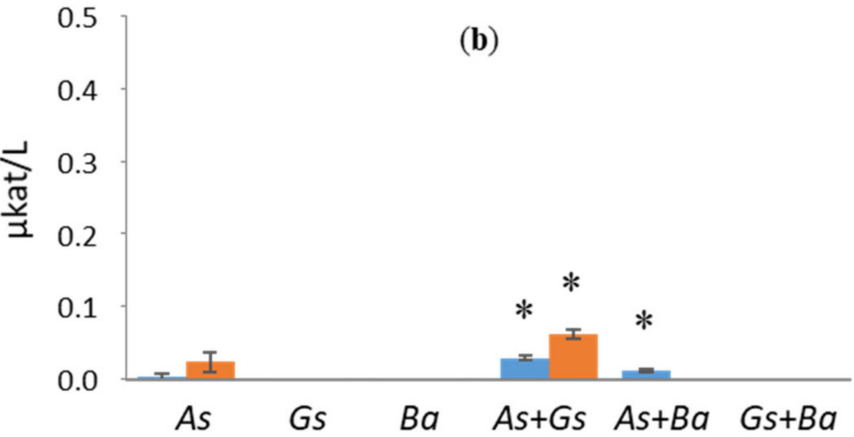

(d)

Figure 10. Laccase (Lcc) activities at early (day 10, marked in blue) and late time points (day 24, marked in red) in single and co-cultivation on (a) birch, (b) spruce, (c) pine wood and (d) Avicel. As = A. sinuosa, Gs = G. sepiarium, Ba=B. adusta, $A s+G s=A$. sinuosa and $G$. sepiarium, $A s+B a=A$. sinuosa and B. adusta, $G s+B a=G$. sepiarium and B. adusta. Error bars refer to standard deviation (SD) $(n=3) .{ }^{*}$ indicates statistical difference among single and co-cultivations $(p<0.05)$. 
Table 1. Hemicellulose- and pectin-derived monosaccharide composition (g/100 g wood (\%)) after fungal cultivations, measured by acid methanolysis. $A s+G s=A$. sinuosa and $G$. sepiarium, $A s+B a=A$. sinuosa and B. adusta, Gs+Ba=G. sepiarium and B. adusta.

\begin{tabular}{|c|c|c|c|c|c|c|c|c|c|}
\hline & & Man & Glu & Xyl & Gal & GalA & Ara & Rha & GlcA \\
\hline Pine wood & & 10.76 & 9.98 & 5.72 & 2.31 & 1.37 & 1.36 & 0.44 & n.d \\
\hline \multirow{6}{*}{ Pine cultured with } & A. sinuosa & 9.13 & 7.38 & 7.51 & 2.53 & 1.22 & 1.62 & 0.48 & n.d \\
\hline & G. sepiarium & $8.47 *$ & 7.30 * & $6.57 *$ & 2.15 & $1.13^{*}$ & 1.45 & 0.45 & n.d \\
\hline & B. adusta & $6.22 *$ & $6.07 *$ & 5.77 & 2.22 & $1.11 *$ & 1.22 & 0.45 & n.d \\
\hline & $A s+G s$ & $8.03 *$ & $6.75 *$ & 6.20 & 2.37 & $1.07^{*}$ & 1.40 & 0.46 & n.d \\
\hline & $A s+B a$ & $6.53 *$ & $6.41 *$ & 5.99 & 3.19 * & $1.19^{*}$ & 1.23 & 0.46 & n.d \\
\hline & $G s+B a$ & $6.73 *$ & $5.68 *$ & 6.07 & $2.75 *$ & $1.12 *$ & 1.34 & 0.46 & n.d \\
\hline \multirow[t]{3}{*}{ Spruce wood } & & 10.30 & 3.84 & 4.42 & 2.13 & 1.46 & 0.79 & 0.42 & n.d \\
\hline & A. sinuosa & 10.30 & 3.14 & $5.84 *$ & 1.70 & 1.72 & 0.96 & $0.66^{*}$ & n.d \\
\hline & G. sepiarium & 10.61 & 3.34 & 5.94 & 2.03 & 1.64 & 0.99 & $0.65 *$ & n.d \\
\hline \multirow{4}{*}{ Spruce cultured with } & B. adusta & 9.45 & 2.95 & 5.36 & 1.93 & 1.57 & 0.89 & $0.67 *$ & n.d \\
\hline & $A s+G s$ & 9.59 & 3.05 & 5.13 & 1.89 & 1.55 & 0.85 & $0.63 *$ & n.d \\
\hline & $A s+B a$ & 9.69 & 3.03 & $5.61 *$ & 1.78 & 1.58 & 0.99 & $0.63 *$ & n.d \\
\hline & $G s+B a$ & 9.42 & 3.06 & 5.49 & 1.95 & 1.62 & 0.94 & $0.64 *$ & n.d \\
\hline \multirow[t]{3}{*}{ Birch wood } & & 0.98 & 7.56 & 21.44 & 1.17 & 2.16 & 0.53 & 0.68 & 0.35 \\
\hline & A. sinuosa & $1.23 *$ & $5.28 *$ & $24.15^{*}$ & 1.74 & 2.11 & $0.69 *$ & $0.79 *$ & n.d \\
\hline & G. sepiarium & $1.17 *$ & $5.16^{*}$ & 22.18 & $1.46^{*}$ & 1.98 & 0.63 * & 0.74 * & n.d \\
\hline \multirow{4}{*}{ Birch cultured with } & B. adusta & $1.74 *$ & $10.47 *$ & 13.19 * & $2.33 *$ & 1.85 & n.d & 0.60 & n.d \\
\hline & $A s+G s$ & 1.11 & $4.73 *$ & 18.34 & 1.93 * & 1.81 & 0.60 & 0.66 & n.d \\
\hline & $A s+B a$ & $1.85^{*}$ & 10.18 & $11.69 *$ & 3.86 * & $1.67^{*}$ & 0.58 & $0.56^{*}$ & n.d \\
\hline & $G s+B a$ & 1.34 & 4.83 & 18.04 & 2.91 & 2.08 & 0.63 & 0.70 & n.d \\
\hline
\end{tabular}

* indicates statistical difference between untreated and fungal treated wood $(p<0.05)$. n.d $=$ not detected.

\section{Discussion}

In natural habitats, plant biomass degradation strongly depends on the activities of fungal communities. The complete and efficient decay requires the combined and diverse activities of multiple fungal species that act simultaneously and synergistically. We have studied lignocellulose-degrading enzyme activities of fungal species, which have been previously shown to be able to grow together on carboxymethyl cellulose (CMC)supplemented agar plates [15]. This decay community included two brown-rot fungi (G. sepiarium and $A$. sinuosa) and one white-rot fungus (B. adusta), which we co-cultivated on wood-supplemented liquid cultivations.

\subsection{Co-Cultivation of White-Rot Fungus, B. adusta, and Brown-Rot Fungus, G. sepiarium}

White-rot fungal species, such as B. adusta, are able to degrade all structural components of the plant cell wall, including lignin $[44,45]$. Although white-rot fungi are predominantly found in hardwood, $B$. adusta is able to colonize and degrade softwood as well [46-49]. In this study, B adusta and G. sepiarium were able to co-exist on softwood; however, most of the additive activities of hydrolytic enzymes were detected in hardwood (birch)-containing co-cultivations. Additionally, synergistic activities of BGL and AGL in co-cultivations were detected on birch-supplemented conditions. In contrast, in the pine- or spruce-containing co-cultivations, BGL activity was not enhanced by fungal interactions. Previously, variation in BGL activity has been detected in conifer-containing interspecific cultivations of brown-rot species, Fomitopsis pinicola, growing together with different white-rot species [29].

In single cultivations, both B. adusta and G. sepiarium showed only moderate EG activities on birch and spruce, whereas in pine, the activities were somewhat higher. Previously, it has been shown that B. adusta produced (hemi)cellulolytic enzymes e.g., GH1, GH3 and GH31, as well as lignin-modifying class II peroxidases during growth on beech wood (Fagus sylvatica) [50]. However, the enzyme activities have not been measured in this proteome study. To be able to follow a wide repertoire of enzyme activities during the 35- 
day cultivation, we have grown the fungi in wood-supplemented submerged cultivations, which cannot be directly compared with the proteome from solid wood. Similarly to $B$. adusta and G. sepiarium, single cultivations of white-rot fungus, Phlebia radiata, and brown rotter, F. pinicola, have shown moderate EG activity when growing on birch [51]. For $B$. adusta and G. sepiarium, the EG activity curve stayed flat for 35 days, whereas P. radiata and brown rotter, F. pinicola, have shown fluctuating EG activity during the cultivation.

CBHI activities of $B$. adusta were low overall, but on birch-supplemented co-cultivation, CBHI activity was significantly enhanced on day 24 compared to other wood substrates or single cultivations. In line with our study, spruce-containing cultivations of white-rot species, Phlebia centrifuga and Dichomitus squalens, have shown only low CBH activities [52,53].

In nature, G. sepiarium colonizes conifer trees [12], but here we show that G. sepiarium grows on birch as well. On birch-supplemented cultivations, xylan degradation-related enzyme activities were enhanced and xylose consumption was detected on B. adusta and G. sepiarium co-cultivations. High MAN and MND activities were detected on all wood supplemented cultivations in both single and co-cultivations of B. adusta and G. sepiarium. This is in line with the reduction of mannose and glucose residues in pine and spruce cultivations, which indicates consumption of these monosaccharides by fungi. Interestingly, MAN activities on pine fluctuated during the cultivation, whereas on spruce and birch cultivations, activities were constant throughout the cultivation period. Similarly, MND activities stayed constant in softwood cultivations, and on birch, there was a slight increase in activity during the cultivation period. In the related species, G. trabeum, high levels of secreted GH10 (xylanases) and GH5 (mannanases) have been detected on spruce wafers [54].

In brown-rot species, non-enzymatic (hemi)cellulose degradation is efficient during the early stages of wood decay [55]. However, high xylanase activity was detected for G. sepiarium in wood cultivations. In line with our results, $\mathrm{XLN}$ activity has been reported to be superior compared to cellulolytic enzyme activities in G. trabeum cultures on pine (Pinus taeda) wood chips [56].

Pectin, a minor component in wood, is present at high levels in bordered pits, which are often the entry points for fungal hyphae to the wood cell walls. We detected pectinderived monosaccharides i.e., galacturonic acid, rhamnose, arabinose and galactose, but there was no clear pattern in their consumption by fungi.

In pine, MnP activity of B. adusta was enhanced by the presence of G. sepiarium, which does not have MnP-encoding genes in its genome (Table S2). Previously, enhanced MnP activity has been detected on co-cultivation of $B$. adusta and white-rot fungus D. squalens [57]. This indicates that $\mathrm{MnP}$ production of $B$. adusta is influenced by the co-existence of other fungal species.

\subsection{Co-Cultivation of White-Rot Fungus, B. adusta, and Brown-Rot Fungus, A. sinuosa}

Co-cultivations of $B$. adusta with brown-rot species, $A$. sinuosa, showed a different pattern of secreted enzyme activities compared to those detected in co-cultivations with $G$. sepiarium. The sequenced genome of $A$. sinuosa indicates that it has ability to breakdown both cellulose and hemicellulose (Table S2). In general, enzyme profiles of B. adusta and A. sinuosa co-cultivations showed no additive effect on softwood-containing cultivations. Only BGL and AGL showed synergistic activity on spruce, and the enzyme activity profile resembled the single cultivation of $B$. adusta. In single cultivations, A. sinuosa showed constant EG activity on all substrates, which has been also previously detected on CMCsupplemented liquid cultivations [15].

The additive effects of enzyme activities were observed for xylan- and mannan-acting enzymes on birch- and spruce-supplemented co-cultivations, respectively, indicating a positive interaction of these species in hemicellulose degradation. This is in line with the reduction of xylose residues in birch, and mannose and glucose residues in spruce after fungal treatment. 
In single cultivations, XLN activity of $B$. adusta was produced towards the end of the cultivation in softwood. Similarly, xylanolytic activity of B. adusta has been detected in softwood- and hardwood-supplemented agar plates after two-week cultivations [49]. Xylanolytic activities of Antrodia species have been previously reported from Antrodia macra and Antrodia pulvinascens, where low XLN and high BXL activities have been measured in defined liquid cultivations [58].

\subsection{Co-Cultivation of Brown-Rot Fungi, G. sepiarium and A. sinuosa}

The interaction of taxonomically different brown-rot fungal species, A. sinuosa and G. sepiarium, indicated that the enzyme-production profile was affected by the co-existence on wood. In nature, this combination is rare, but a positive effect on degradation of spruce has been detected in the three species co-cultivation with white-rot species, Phlebiopsis gigantea [32]. We cultivated these brown-rot species on spruce and pine, as well as on birch, which is not a natural substrate for either of these brown-rot species. However, species in the Antrodia-Fomitopsis clade have been suggested to be generalists in degradation of both angiosperms and gymnosperm species in nature [59].

At early stages of co-cultivation, synergy in BGL production was detected on birch and spruce. BXL activity was enhanced in all substrates in co-cultivations, whereas XLN activity of $G$. sepiarium was inhibited by the presence of $A$. sinuosa. The reduced amount of xylose was detected only in birch-containing cultivations. In line with our findings, the interaction of G. trabeum, which is a related species to G. sepiarium, and Rhodonia placenta, which belongs to the same clade as $A$. sinuosa, have shown lower XLN activity in the interaction zone compared with single cultivations or co-cultivation outside the interacting hyphae, when grown on aspen [18]. However, no synergy or elevated production of BGL was detected in the interaction zone of G. trabeum and R. placenta.

In softwood, mannanolytic activities were higher in co-cultivations compared to single ones, which could also be observed in the reduced amount of mannose and glucose in fungal-treated spruce and pine. However, AGL activities were inhibited on softwood, whereas on pine- and birch-supplemented cultivations, the interaction of $A$. sinuosa and G. sepiarium caused synergistic activity at the later stages of the cultivation period.

Laccase activity was slightly enhanced on spruce and birch, which may indicate elevated stress in co-cultivations. Induced laccase activity in interspecific interactions has been reported to be related to the enhanced formations of melanin, which is suggested to protect the fungus against hydrolytic enzymes in the interaction zone [60]. In addition, laccase activity plays a defensive role in stressful conditions by degrading toxic metabolites during antagonistic fungal interactions [25,61].

In natural wood-inhabiting fungal communities, the interspecific interactions are dynamic processes [20]. The community development is dependent on both wood species and abiotic factors; therefore, the same combinations of fungal species may result in different interaction outcomes [62]. In addition, priority effects in the early stages of colonization, the ability to produce secondary metabolites in competitive interactions and the spatial orientation of fungal species have an impact on the fungal interaction in nature [60]. The different lignocellulose-modifying enzyme activities produced by positively interacting fungal species increase heterogeneity in the structure of degrading wood, which benefits utilization of nutrient resources by fungi.

\section{Conclusions}

To study enzymatic wood decay, we co-cultivated white-rot and brown-rot species in pairwise combinations in the presence of hardwood or softwood sawdust as a carbon source. The interaction of white-rot and brown-rot species showed enhanced (hemi)cellulase activities on birch- and spruce-supplemented cultivations. Based on the enzyme activity profiles and xylan degradation, the combination of B. adusta and G. sepiarium facilitated birch wood degradation, whereas $B$. adusta and $A$. sinuosa is a promising combination for 
efficient degradation of spruce wood. Our findings indicate that interspecific interactions of fungal species have a positive effect on the enzymatic degradation of wood.

Supplementary Materials: The following are available online at https:/ /www.mdpi.com/article/10 .3390/jof7040265/s1, Table S1: (Hemi) cellulose and lignin degrading enzymes; Table S2: Number of putative CAZyme encoding gene models in the genomes of B. adusta, A. sinuosa and G. trabeum; Figure S1: Endoglucanase (EG) activities on woody substrates and Avicel in single cultivations, a) A. sinuosa, b) G. sepiarium, and c) B. adusta, and in co-cultivations, d) A. sinuosa and G. sepiarium, e) A. sinuosa and B. adusta, and f) G. sepiarium and B. adusta. Error bars refer to standard deviation (SD) $(n=3)$; Figure S2: $\beta$-glucosidase (BGL) activities on woody substrates and Avicel in single cultivations, a) A. sinuosa, b) G. sepiarium, and c) B. adusta, and in co-cultivations, d) A. sinuosa and G. sepiarium, e) A. sinuosa and B. adusta, and f) G. sepiarium and B. adusta. Error bars refer to standard deviation (SD) $(n=3)$; Figure S3: Cellobiohydrolase I (CBHI) activities on woody substrates and Avicel in single cultivation of a) B. adusta, and in co-cultivations, b) A. sinuosa and B. adusta, and c) G. sepiarium and B. adusta. Error bars refer to standard deviation (SD) $(n=3)$; Figure S4: Endoxylanase (XLN) activities on woody substrates and Avicel in single cultivations, a) A. sinuosa, b) G. sepiarium, and c) B. adusta, and in co-cultivations, d) A. sinuosa and G. sepiarium, e) A. sinuosa and B. adusta, and f) G. sepiarium and B. adusta. Error bars refer to standard deviation (SD) $(n=3)$; Figure S5: $\beta$-xylosidase (BXL) activities on woody substrates and Avicel in single cultivations, a) A. sinuosa, b) G. sepiarium, and c) B. adusta, and in co-cultivations, d) A. sinuosa and G. sepiarium, e) A. sinuosa and B. adusta, and f) G. sepiarium and B. adusta. Error bars refer to standard deviation (SD) $(n=3)$; Figure S6: $\beta$-xylosidase (BXL) activities on woody substrates and Avicel in single cultivations, a) A. sinuosa, b) G. sepiarium, and c) B. adusta, and in co-cultivations, d) A. sinuosa and G. sepiarium, e) A. sinuosa and $B$. adusta, and f) G. sepiarium and B. adusta. Error bars refer to standard deviation (SD) $(n=3)$; Figure S7: $\beta$-mannosidase (MND) activities on Avicel and woody substrates in single cultivations, a) A. sinuosa, b) G. sepiarium, and c) B. adusta, and in co-cultivations, d) A. sinuosa and G. sepiarium, e) A. sinuosa and B. adusta, and f) G. sepiarium and B. adusta. Error bars refer to standard deviation (SD) $(n=3)$; Figure S8: $\alpha$-galactosidase (AGL) activities on woody substrates and Avicel in single cultivations, a) A. sinuosa, b) G. sepiarium, and c) B. adusta, and in co-cultivations, d) A. sinuosa and G. sepiarium, e) A. sinuosa and B. adusta, and f) G. sepiarium and B. adusta. Error bars refer to standard deviation (SD) $(n=3)$; Figure S9: Manganese peroxidase $(\mathrm{MnP})$ activities on woody substrates and Avicel in single cultivations of a) B. adusta, and in co-cultivations, b) A. sinuosa and B. adusta, and c) G. sepiarium and B. adusta. Error bars refer to standard deviation (SD) $(n=3)$

Author Contributions: Conceptualization methodology and validation, J.S., N.M., J.W. and K.H.; formal analysis and investigation, J.S.; resources, N.M. and K.H.; data curation, J.S.; writing-original draft preparation, J.S.; writing-review and editing, K.H.; visualization, J.S.; supervision, project administration, K.H.; funding acquisition, J.S. and K.H. All authors have read and agreed to the published version of the manuscript.

Funding: Open access funding provided by University of Helsinki. This research was funded by Academy of Finland, grant number 297847 (KH) and Fortum Foundation, grant numbers 201800106, 20190149, and 20200031 (JS).

Institutional Review Board Statement: Not applicable.

Informed Consent Statement: Not applicable.

Data Availability Statement: Not applicable.

Conflicts of Interest: The authors declare no conflict of interest.

\section{References}

1. Hatakka, A.; Hammel, K.E. Fungal Biodegradation of Lignocelluloses. In Industrial Applications; Hofrichter, M., Ed.; Springer: Berlin/Heidelberg, Germany, 2011; pp. 319-340, ISBN 978-3-642-11458-8.

2. Lundell, T.K.; Mäkelä, M.R.; de Vries, R.P.; Hildén, K.S. Genomics, lifestyles and future prospects of wood-decay and litterdecomposing basidiomycota. Adv. Bot. Res. 2014, 70, 329-370. [CrossRef]

3. Rytioja, J.; Hildén, K.; Yuzon, J.; Hatakka, A.; de Vries, R.P.; Mäkelä, M.R. Plant-polysaccharide-degrading enzymes from basidiomycetes. Microbiol. Mol. Biol. Rev. 2014, 78, 614-649. [CrossRef] [PubMed] 
4. Sjöström, E. Wood Chemistry: Fundamentals and Applications; Sjöström, E., Alén, R., Eds.; Academic Press: San Diego, CA, USA, 1993.

5. Mäkelä, M.R.; Hildén, K.S.; de Vries, R.P. Degradation and modification of plant biomass by Fungi. In Fungal Genomics; Nowrousian, M., Ed.; Springer: Berlin/Heidelberg, Germany, 2014; pp. 175-208, ISBN 978-3-642-45218-5.

6. Riley, R.; Salamov, A.A.; Brown, D.W.; Nagy, L.G.; Floudas, D.; Held, B.W.; Levasseur, A.; Lombard, V.; Morin, E.; Otillar, R.; et al. Extensive sampling of basidiomycete genomes demonstrates inadequacy of the white-rot/brown-rot paradigm for wood decay fungi. Proc. Natl. Acad. Sci. USA 2014, 111, 9923-9928. [CrossRef] [PubMed]

7. Koenigs, J.W. Production of hydrogen peroxide by wood-rotting fungi in wood and its correlation with weight loss, depolymerization, and pH changes. Arch. Microbiol. 1974, 99, 129-145. [CrossRef]

8. Rättö, M.; Ritschkoff, A.C.; Viikari, L. The effect of oxidative pretreatment on cellulose degradation by Poria placenta and Trichoderma reesei cellulases. Appl. Microbiol. Biotechnol. 1997, 48, 53-57. [CrossRef]

9. Renvall, P. Community structure and dynamics of wood-rotting basidiomycetes on decomposing conifer trunks in northern Finland. Karstenia 1995, 35, 1-51. [CrossRef]

10. Lindblad, I. Wood-inhabiting fungi on fallen logs of Norway spruce: Relations to forest management and substrate quality. Nord. J. Bot. 1998, 18, 243-255. [CrossRef]

11. Matheron, M.E.; Porchas, M.; Bigelow, D.M. Factors affecting the development of wood rot on lemon trees infected with Antrodia sinuosa, Coniophora eremophila, and a Nodulisporium sp. Plant Dis. 2006, 90, 554-558. [CrossRef] [PubMed]

12. Jönsson, M.T.; Edman, M.; Jonsson, B.G. Colonization and extinction patterns of wood-decaying fungi in a boreal old-growth Picea abies forest. J. Ecol. 2008, 96, 1065-1075. [CrossRef]

13. Olsson, J.; Jonsson, B.G. Restoration fire and wood-inhabiting fungi in a Swedish Pinus sylvestris forest. For. Ecol. Manag. 2010, 259, 1971-1980. [CrossRef]

14. Haas, D.; Mayrhofer, H.; Habib, J.; Galler, H.; Reinthaler, F.F.; Fuxjäger, M.L.; Buzina, W. Distribution of building-associated wood-destroying fungi in the federal state of Styria, Austria. Eur. J. Wood Wood Prod. 2019, 77, 527-537. [CrossRef]

15. Sugano, J.; Linnakoski, R.; Huhtinen, S.; Pappinen, A.; Niemelä, P.; Asiegbu, F.O. Cellulolytic activity of brown-rot Antrodia sinuosa at the initial stage of cellulose degradation. Holzforschung 2019, 73, 673-680. [CrossRef]

16. Garcia-Sandoval, R.; Wang, Z.; Binder, M.; Hibbett, D.S. Molecular phylogenetics of the Gloeophyllales and relative ages of clades of Agaricomycotina producing a brown rot. Mycologia 2011, 103, 510-524. [CrossRef] [PubMed]

17. Floudas, D.; Binder, M.; Riley, R.; Barry, K.; Blanchette, R.A.; Henrissat, B.; Martínez, A.T.; Otillar, R.; Spatafora, J.W.; Yadav, J.S.; et al. The paleozoic origin of enzymatic lignin decomposition reconstructed from 31 fungal genomes. Science 2012, 336, 1715-1719. [CrossRef]

18. Presley, G.N.; Zhang, J.; Purvine, S.O.; Schilling, J.S. Functional genomics, transcriptomics, and proteomics reveal distinct combat strategies between lineages of wood-degrading fungi with redundant wood decay mechanisms. Front. Microbiol. 2020, 11, 1646. [CrossRef] [PubMed]

19. Owens, E.M.; Reddy, C.A.; Grethlein, H.E. Outcome of interspecific interactions among brown-rot and white-rot wood decay fungi. FEMS Microbiol. Ecol. 1994, 14, 19-24. [CrossRef]

20. Boddy, L. Interspecific combative interactions between wood-decaying basidiomycetes. FEMS Microbiol. Ecol. 2000, 31, 185-194. [CrossRef]

21. Hiscox, J.; Savoury, M.; Müller, C.T.; Lindahl, B.D.; Rogers, H.J.; Boddy, L. Priority effects during fungal community establishment in beech wood. ISME J. 2015, 14, 24-32. [CrossRef]

22. Kubartová, A.; Ottosson, E.; Dahlberg, A.; Stenlid, J. Patterns of fungal communities among and within decaying logs, revealed by 454 sequencing. Mol. Ecol. 2012, 21, 4514-4532. [CrossRef]

23. Ovaskainen, O.; Hottola, J.; Shtonen, J. Modeling species co-occurrence by multivariate logistic regression generates new hypotheses on fungal interactions. Ecology 2010, 91, 2514-2521. [CrossRef]

24. Ottosson, E.; Nordén, J.; Dahlberg, A.; Edman, M.; Jönsson, M.; Larsson, K.H.; Olsson, J.; Penttilä, R.; Stenlid, J.; Ovaskainen, O. Species associations during the succession of wood-inhabiting fungal communities. Fungal Ecol. 2014, 11, 17-28. [CrossRef]

25. Baldrian, P. Increase of laccase activity during interspecific interactions of white-rot fungi. FEMS Microbiol. Ecol. 2004, 50, 245-253. [CrossRef] [PubMed]

26. Toljander, Y.K.; Lindahl, B.D.; Holmer, L.; Högberg, N.O.S. Environmental fluctuations facilitate species co-existence and increase decomposition in communities of wood decay fungi. Oecologia 2006, 148, 625-631. [CrossRef] [PubMed]

27. Van Der Wal, A.; Ottosson, E.; De Boer, W. Neglected role of fungal community composition in explaining variation in wood decay rates. Ecology 2015, 96, 124-133. [CrossRef]

28. Noll, L.; Leonhardt, S.; Arnstadt, T.; Hoppe, B.; Poll, C.; Matzner, E.; Hofrichter, M.; Kellner, H. Fungal biomass and extracellular enzyme activities in coarse woody debris of 13 tree species in the early phase of decomposition. For. Ecol. Manag. 2016, 378, 181-192. [CrossRef]

29. Mali, T.; Kuuskeri, J.; Shah, F.; Lundell, T.K. Interactions affect hyphal growth and enzyme profiles in combinations of coniferous wood-decaying fungi of Agaricomycetes. PLoS ONE 2017, 12, e0185171. [CrossRef]

30. Mali, T.; Mäki, M.; Hellén, H.; Heinonsalo, J.; Bäck, J.; Lundell, T. Decomposition of spruce wood and release of volatile organic compounds depend on decay type, fungal interactions and enzyme production patterns. FEMS Microbiol. Ecol. 2019, 95 , fiz135. [CrossRef] 
31. Sperandio, G.B.; Ferreira Filho, E.X. Fungal co-cultures in the lignocellulosic biorefinery context: A review. Int. Biodeterior. Biodegrad. 2019, 142, 109-123. [CrossRef]

32. Sugano, J.; Awan, H.U.M.; Asiegbu, F.O. Effect of interspecific fungal interactions on wood decomposition. Manuscript in preparation.

33. Hatakka, A.I.; Uusi-Rauva, A.K. Degradation of ${ }^{14}$ C-labelled poplar wood lignin by selected white-rot fungi. Eur. J. Appl. Microbiol. Biotechnol. 1983, 17, 235-242. [CrossRef]

34. Wood, T.M.; Bhat, K.M. Methods for measuring cellulase activities. In Methods in Enzymology; Academic Press: Cambridge, MA, USA, 1988; Volume 160, pp. 87-112, ISBN 0076-6879.

35. Bailey, M.J.; Nevalainen, K.M.H. Induction, isolation and testing of stable Trichoderma reesei mutants with improved production of solubilizing cellulase. Enzyme Microb. Technol. 1981, 3, 153-157. [CrossRef]

36. Ko, K.C.; Han, Y.; Choi, J.H.; Kim, G.J.; Lee, S.G.; Song, J.J. A novel bifunctional endo-/exo-type cellulase from an anaerobic ruminal bacterium. Appl. Microbiol. Biotechnol. 2011, 89, 1453-1462. [CrossRef]

37. Benoit, I.; Culleton, H.; Zhou, M.; DiFalco, M.; Aguilar-Osorio, G.; Battaglia, E.; Bouzid, O.; Brouwer, C.P.J.M.; El-Bushari, H.B.O.; Coutinho, P.M.; et al. Closely related fungi employ diverse enzymatic strategies to degrade plant biomass. Biotechnol. Biofuels 2015, 8, 107. [CrossRef]

38. Presley, G.N.; Panisko, E.; Purvine, S.O.; Schilling, J.S. Coupling secretomics with enzyme activities to compare the temporal processes of wood metabolism among white and brown rot fungi. Appl. Environ. Microbiol. 2018, 84, e00159-18. [CrossRef]

39. Slomczynski, D.; Nakas, J.P.; Tanenbaum, S.W. Production and characterization of laccase from Botrytis cinerea 61-34. Appl. Environ. Microbiol. 1995, 61, 907-912. [CrossRef] [PubMed]

40. Wariishi, H.; Valli, K.; Gold, M.H. Manganese(II) oxidation by manganese peroxidase from the basidiomycete Phanerochaete chrysosporium: Kinetic mechanism and role of chelators. J. Biol. Chem. 1992, 267, 23688-23695. [CrossRef]

41. R Foundation for Statistical Computing. A Language and Environment for Statistical Computing; R Foundation for Statistical Computing: Vienna, Austria, 2018; ISBN 3900051070.

42. Laine, C.; Tamminen, T.; Vikkula, A.; Vuorinen, T. Methylation analysis as a tool for structural analysis of wood polysaccharides. Holzforschung 2002, 56, 607-614. [CrossRef]

43. Sundberg, A.; Sundberg, K.; Lillandt, C.; Holmbom, B. Determination of hemicelluloses and pectins in wood and pulp fibres by acid methanolysis and gas chromatography. Nord. Pulp Pap. Res. J. 1996, 11, 216-219. [CrossRef]

44. Kirk, T.K.; Farrell, R.L. Enzymatic “combustion": The microbial degradation of lignin. Annu. Rev. Microbiol. 1987, 41, 465-505. [CrossRef]

45. Stokland, J.N.; Siitonen, J.; Jonsson, B.G. Biodiversity in Dead Wood; Cambridge University Press: Cambridge, UK, 2012; pp. 18-20, ISBN 9781139025843.

46. Dorado, J.; Van Beek, T.A.; Claassen, F.W.; Sierra-Alvarez, R. Degradation of lipophilic wood extractive constituents in Pinus sylvestris by the white-rot fungi Bjerkandera sp. and Trametes versicolor. Wood Sci. Technol. 2001, 35, 117-125. [CrossRef]

47. Lindhe, A.; Åsenblad, N.; Toresson, H.G. Cut logs and high stumps of spruce, birch, aspen and oak-Nine years of saproxylic fungi succession. Biol. Conserv. 2004, 119, 443-454. [CrossRef]

48. Hakala, T.K.; Maijala, P.; Konn, J.; Hatakka, A. Evaluation of novel wood-rotting polypores and corticioid fungi for the decay and biopulping of Norway spruce (Picea abies) wood. Enzyme Microb. Technol. 2004, 34, 255-263. [CrossRef]

49. Quiroz-Castañeda, R.E.; Pérez-Mejía, N.; Martínez-Anaya, C.; Acosta-Urdapilleta, L.; Folch-Mallol, J. Evaluation of different lignocellulosic substrates for the production of cellulases and xylanases by the basidiomycete fungi Bjerkandera adusta and Pycnoporus sanguineus. Biodegradation 2011, 22, 565-572. [CrossRef]

50. Moody, S.C.; Dudley, E.; Hiscox, J.; Boddy, L.; Eastwood, D.C. Interdependence of primary metabolism and xenobiotic mitigation characterizes the proteome of Bjerkandera adusta during wood decomposition. Appl. Environ. Microbiol. 2018, 84, e01401-17. [CrossRef] [PubMed]

51. Villavicencio, E.V.; Mali, T.; Mattila, H.K.; Lundell, T. Enzyme activity profiles produced on wood and straw by four fungi of different decay strategies. Microorganisms 2020, 8, 73. [CrossRef]

52. Kuuskeri, J.; Mäkelä, M.R.; Isotalo, J.; Oksanen, I.; Lundell, T. Lignocellulose-converting enzyme activity profiles correlate with molecular systematics and phylogeny grouping in the incoherent genus Phlebia (Polyporales, Basidiomycota) Ecological and evolutionary microbiology. BMC Microbiol. 2015, 15, 217. [CrossRef] [PubMed]

53. Casado López, S.; Theelen, B.; Manserra, S.; Issak, T.Y.; Rytioja, J.; Mäkelä, M.R.; de Vries, R.P. Functional diversity in Dichomitus squalens monokaryons. IMA Fungus 2017, 8, 17-25. [CrossRef] [PubMed]

54. Presley, G.N.; Schilling, J.S. Distinct growth and secretome strategies for two taxonomically divergent brown rot fungi. Appl. Environ. Microbiol. 2017, 83, e02987-16. [CrossRef] [PubMed]

55. Arantes, V.; Goodell, B. Current understanding of brown-rot fungal biodegradation mechanisms: A review. ACS Symp. Ser. 2014, 1158, 3-21. [CrossRef]

56. Aguiar, A.; Gavioli, D.; Ferraz, A. Extracellular activities and wood component losses during Pinus taeda biodegradation by the brown-rot fungus Gloeophyllum trabeum. Int. Biodeterior. Biodegrad. 2013, 82, 187-191. [CrossRef]

57. Qi-He, C.; Krügener, S.; Hirth, T.; Rupp, S.; Zibek, S. Co-cultured production of lignin-modifying enzymes with white-rot fungi. Appl. Biochem. Biotechnol. 2011, 165, 700-718. [CrossRef] 
58. Tomšovský, M.; Popelářová, P.; Baldrian, P. Production and regulation of lignocellulose-degrading enzymes of Poria-like wood-inhabiting basidiomycetes. Folia Microbiol. 2009, 54, 74-80. [CrossRef] [PubMed]

59. Krah, F.S.; Bässler, C.; Heibl, C.; Soghigian, J.; Schaefer, H.; Hibbett, D.S. Evolutionary dynamics of host specialization in wood-decay fungi. BMC Evol. Biol. 2018, 18, 119. [CrossRef] [PubMed]

60. Hiscox, J.; Boddy, L. Armed and dangerous-Chemical warfare in wood decay communities. Fungal Biol. Rev. 2017, 31, 169-184. [CrossRef]

61. Hiscox, J.; Baldrian, P.; Rogers, H.J.; Boddy, L. Changes in oxidative enzyme activity during interspecific mycelial interactions involving the white-rot fungus Trametes versicolor. Fungal Genet. Biol. 2010, 47, 562-571. [CrossRef]

62. Huisman, J.; Weissing, F.J. Fundamental unpredictability in multispecies competition. Am. Nat. 2001, 157, 488-494. [CrossRef] [PubMed] 